\title{
Effects of land-use patterns on in-stream nitrogen in a highly-polluted river basin in Northeast China
}

\author{
Hongmei Bu ${ }^{\mathrm{a}, *}$, Yuan Zhang ${ }^{\mathrm{b}}$, Wei Meng ${ }^{\mathrm{b}}$, Xianfang Song ${ }^{\mathrm{a}}$ \\ ${ }^{a}$ Key Laboratory of Water Cycle and Related Land Surface Processes, Institute of Geographic Sciences and Natural Resources Research, Chinese Academy of Sciences, Beijing 100101, China \\ b State Key Laboratory of Environmental Criteria and Risk Assessment, Chinese Research Academy of Environmental Sciences, Beijing 100012, China
}

\section{H I G H L I G H T S}

- Land-use types were correlated well with most nitrogen variables over seasons.

- Built-up land dominated in predicting nitrogen variables during different seasons.

- Shape metrics predicted most nitrogen variables in different seasons.

- Nitrogen sources and their contributions were estimated using nitrate isotopes.

- Domestic sewage mainly contributed to river nitrogen pollution in residence zone.
G R A P H I C A L A B S T R A C T

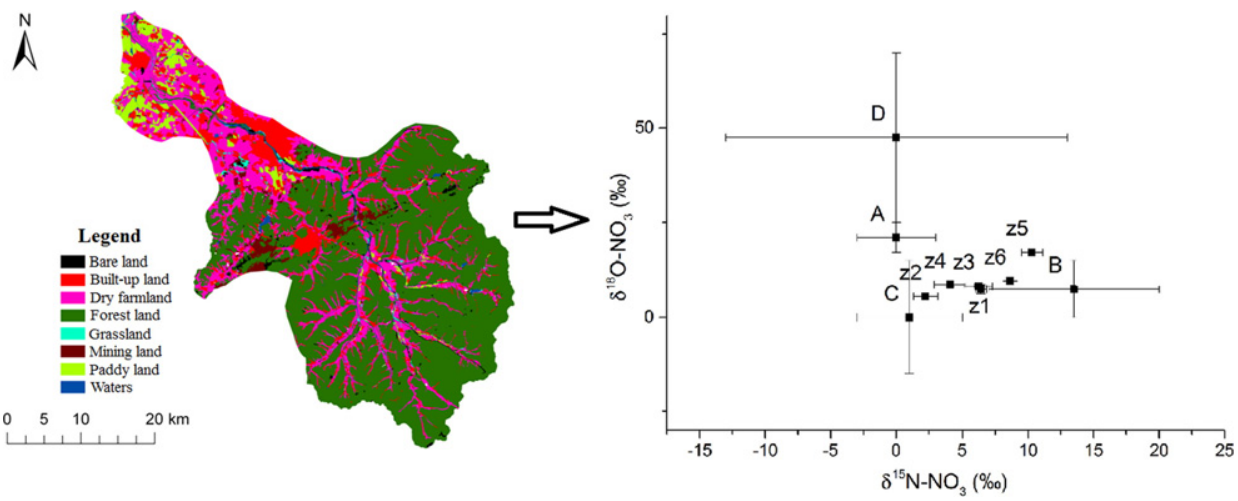

\section{A R T I C L E I N F O}

\section{Article history:}

Received 17 August 2015

Received in revised form 7 December 2015

Accepted 15 February 2016

Available online 27 February 2016

Editor: D. Barcelo

\section{Keywords:}

Land use

Landscape metrics

Nitrogen pollution

Nitrate isotopes

Nitrogen source contributions

Isotope mixing models

\begin{abstract}
A B S T R A C T
This study investigated the effects of land-use patterns on nitrogen pollution in the Haicheng River basin in Northeast China during 2010 by conducting statistical and spatial analyses and by analyzing the isotopic composition of nitrate. Correlation and stepwise regressions indicated that land-use types and landscape metrics were correlated well with most river nitrogen variables and significantly predicted them during different sampling seasons. Built-up land use and shape metrics dominated in predicting nitrogen variables over seasons. According to the isotopic compositions of river nitrate in different zones, the nitrogen sources of the river principally originated from synthetic fertilizer, domestic sewage/manure, soil organic matter, and atmospheric deposition. Isotope mixing models indicated that source contributions of river nitrogen significantly varied from forested headwaters to densely populated towns of the river basin. Domestic sewage/manure was a major contributor to river nitrogen with the proportions of $76.4 \pm 6.0 \%$ and $62.8 \pm 2.1 \%$ in residence and farmland-residence zones, respectively. This research suggested that regulating built-up land uses and reducing discharges of domestic sewage and industrial wastewater would be effective methods for river nitrogen control.
\end{abstract}

(c) 2016 Elsevier B.V. All rights reserved.

\footnotetext{
* Corresponding author at: Institute of Geographic Sciences and Natural Resources Research, Chinese Academy of Sciences, Datun Road, A 11, Beijing 100101, China.

E-mail address: buhm2004@163.com (H. Bu).
}

\section{Introduction}

Changes in land-use patterns have dramatically affected the river water quality by altering the natural appearance, material circulation, and energy distribution of landscapes within watershed ecosystems 
(Lee et al., 2009; Tran et al., 2010; Rothwell et al., 2010; Bu et al., 2014; Wilson, 2015). In-stream nitrogen pollution is due to alterations of runoff, non-point source pollution production, and nutrient transportation driven by land-use changes (Mattikalli and Richards, 1996; Wilson, 2015). Generally, crop land within a watershed has a strong influence on nitrogen loadings in river water due to the utilization of nitrogen fertilizers (Ngoye and Machiwa, 2004; Woli et al., 2004; Wang et al., 2014). Expansion of built-up land including industrial and urban land uses also results in increased nitrogen in river water due to the nitrogenous wastewater discharges (Schoonover and Lockaby, 2006; Wilson, 2015). Forest lands can provide mitigating and removing effects on riverine nitrogen due to their fixation and absorption effects for nutrients (Nakagawa and Iwatsubo, 2000; Piatek et al., 2009; Bu et al., 2014). Consequently, land-use patterns to some degree determine in-stream nitrogen concentrations.

The pollution sources of river nitrogen can be identified by the dual isotopic composition of nitrate $\left(\delta^{15} \mathrm{~N}-\mathrm{NO}_{3}\right.$ and $\left.\delta^{18} \mathrm{O}-\mathrm{NO}_{3}\right)$. The isotopic compositions of atmospheric nitrogen deposition range from $-13 \%$ o to $+13 \%$ for $\delta^{15} \mathrm{~N}^{-\mathrm{NO}_{3}}$ (Lee et al., 2008; Xue et al., 2009) and from $25 \%$ o to $70 \%$ for $\delta^{18} \mathrm{O}-\mathrm{NO}_{3}$ (Kendall et al., 2007). Nitrate originating from manure or sewage is usually characterized by $\delta^{15} \mathrm{~N}-\mathrm{NO}_{3}$ values between $+7 \%$ and $+20 \%$ or more (Mayer et al., 2002) and $\delta^{18} \mathrm{O}-\mathrm{NO}_{3}$ values between $0 \%$ o to $15 \%$ o (Kendall et al., 2007), which is isotopically distinct from nitrate in synthetic fertilizers $\left(-3 \%\right.$ 。 to $+3 \%$ 。 $\delta^{15} \mathrm{~N}-\mathrm{NO}_{3}$ and $17 \%$ to $25 \%$ 。 $\delta^{18} \mathrm{O}-\mathrm{NO}_{3}$ ) and natural soil organic matter ( $-3 \%$ to $+5 \% \delta^{15} \mathrm{~N}-\mathrm{NO}_{3}$ and $-15 \%$ to $15 \%$ 。 $\delta^{18} \mathrm{O}-\mathrm{NO}_{3}$ ) (Kendall et al., 2007; Lee et al., 2008). The possible sources of nitrogen in rivers thus include synthetic fertilizer, domestic sewage/manure, soil organic matter, and atmospheric deposition.

The main factor influencing the nitrogen runoff in watersheds is landscape structure, especially land-use composition and its spatial configuration (Uuemaa et al., 2005). Land-use composition not only affects the watershed hydrological system but also closely relates to nitrogen inputs (Wang et al., 2014). The land-use spatial configuration is the most direct landscape characteristic influencing hydrological processes and nutrient cycles within watersheds (Turner et al., 2001; Woli et al., 2004; Bu et al., 2014). Landscape metrics that reflect the structural composition and spatial configuration of landscape patterns are directly or indirectly correlated with river nitrogen levels (Lee et al., 2009; Tran et al., 2010; Rothwell et al., 2010). Consequently, spatial analysis metrics and methods are suitable for quantifying the relationship between landscape patterns and nitrogen concentrations in watersheds.

Because river nitrogen pollution is induced by the changes of land-use patterns (Mattikalli and Richards, 1996; Uuemaa et al., 2005; Lee et al., 2009; Bu et al., 2014; Wilson, 2015), most studies have focused on the relationships between land use and riverine nitrogen (Bahar et al., 2008; Wang et al., 2014). Researchers seldom use isotope mixing models to link nitrogen sources and loadings from land use types and structure in watersheds. This study applies land-use analysis with geographical information systems in combination with natural-abundance isotope values of nitrate and source mixing models to evaluate the effects of land-use patterns on riverine nitrogen and calculate the contributions of different nitrogen sources in the Haicheng River basin in Northeast China. The Haicheng River is suffering serious nitrogen pollution and is contributing to the eutrophication of coastal ecosystems; its total nitrogen (TN) and nitrate nitrogen $\left(\mathrm{NO}_{3}-\mathrm{N}\right)$ concentrations have reached to high levels (Bu et al., 2011). However, the influence of land-use patterns on river nitrogen is unknown in rivers with such high nitrogen pollution. Thus, the objectives of the current study are to: (1) investigate the effects of land-use types on river nitrogen pollution, (2) evaluate the effects of landscape pattern metrics on river nitrogen pollution, and (3) identify the principal sources of nitrogen pollution and calculate their contributions to river nitrogen using stable nitrate isotopes.

\section{Materials and methods}

\subsection{Study area}

The Haicheng River $\left(40.48^{\circ}-41.01^{\circ} \mathrm{N}, 122.48^{\circ}-123.14^{\circ} \mathrm{E}\right)$ is a branch of the Taizi River in Northeast China. The river watershed covers an area of $1249.3 \mathrm{~km}^{2}$ and drains a total length of $87.5 \mathrm{~km}$ in Haicheng City of Liaoning Province, Northeast China (Fig. 1a). It discharges an average of $2.17 \mathrm{~m}^{3} / \mathrm{s}$ monitored at Longquan gaging station (Fig. 1a). The Haicheng River originates from Mt. Xiongdi in the southeast of Gushan Town, and then flows through Ximu Town, Haicheng City, Dongsi Town, Zhongxiao Town, and Niuzhuang Town in the direction of river flow. Finally, the river discharges into the Bohai Sea at Liaodong Bay after a confluence with the Taizi River (Fig. 1a).

The river basin is situated in a warm temperate monsoon climate zone and has four distinct seasons and abundant rainfall. The annual temperature in the basin ranges from $-21.1^{\circ} \mathrm{C}$ (in winter) to $35.9{ }^{\circ} \mathrm{C}$ (in summer) with an average of $10.4{ }^{\circ} \mathrm{C}$. The annual average rainfall is $701.7 \mathrm{~mm}$, and most rainfall occurs in summer (from June to August). The river flow co-varies with the rainfall because of the seasonality of the river, and has a peak discharge in summer season. The main soil types of the river basin include chromic cambisol, haplic phaeozem, cumulic hapludoll, and udic haplustalf (FAO, 2006). The vegetation coverage comprises $52.9 \%$ of the whole basin (Fig. 1b), including 3.6\% of some orchards and managed forests for timber and firewood. Agricultural land covers $34.3 \%$ in the river basin, whereas built-up land is intensive in the middle and lower reaches of the river, covering $10.3 \%$ of the total area. The main farm crops along the river are maize and rice during the crop growing seasons from spring to autumn. The population in the river basin comprises 489,000 people (2010), most of whom live in rural areas (LHSB, 2011). Industries in the river basin principally include mining, mineral processing, textile printing and dyeing, and paper industries.

\subsection{Water sampling and analytical methods}

Four water sampling surveys were conducted in April, June, August, and October of 2010. The first sampling survey was set in spring before crop planting and fertilizer applications to local fields. The second sampling survey was in early summer, generally after cultivation and during fertilizer application. The third and fourth sampling surveys were conducted in late summer during significant runoff events and in fall after crop harvest. In each survey, thirty sampling sites (sites 1-30) were selected from the Haicheng River and its tributaries (Fig. 1a). The sampling strategy for the water sampling sites has been described previously (Bu et al., 2011).

River water was sampled in polyethylene plastic bottles which were prerinsed thrice with distilled water and then stored below $4{ }^{\circ} \mathrm{C}$ for the laboratory analysis of ammoniacal nitrogen $\left(\mathrm{NH}_{3}-\mathrm{N}\right), \mathrm{NO}_{3}-\mathrm{N}$, nitrite nitrogen $\left(\mathrm{NO}_{2}-\mathrm{N}\right)$, and $\mathrm{TN}$. Water samples for $\mathrm{NH}_{3}-\mathrm{N}, \mathrm{NO}_{3}-\mathrm{N}$, and $\mathrm{NO}_{2}-\mathrm{N}$ analyses were filtered with $0.45 \mu \mathrm{m}$ pore size and $47 \mathrm{~mm}$ diameter membrane filters (MF-Millipore, USA) in the field. For measuring all nitrogen variables, water samples were also acidified to $\mathrm{pH}<2$ by sulfuric acid in situ and then were stored in polyethylene bottles for laboratory analyses.

Analyses were all conducted according to the national standard methods (NEPB, 2002). In the laboratory analyses, $\mathrm{NH}_{3}-\mathrm{N}$ and $\mathrm{NO}_{2}-\mathrm{N}$ were respectively determined by using Nessler's reagent and $\mathrm{N}$-(1naphthyl) ethylenediamine dihydrochloride spectrophotometry methods. $\mathrm{NO}_{3}-\mathrm{N}$ and $\mathrm{TN}$ were all quantified by alkaline potassium persulfate oxidation-UV spectrophotometry method. Detection limits of $\mathrm{NH}_{3}-\mathrm{N}, \mathrm{NO}_{3}-\mathrm{N}, \mathrm{NO}_{2}-\mathrm{N}$, and TN were $0.025,0.02,0.003$, and $0.05 \mathrm{mg} / \mathrm{L}$, respectively.

Water samples for measuring stable isotope compositions of $\mathrm{N}-\mathrm{NO}_{3}$ and $\mathrm{O}-\mathrm{NO}_{3}$ were prepared through anion exchange resins following the procedures described by Silva et al. (2000). The samples were eluted and then purified to produce silver nitrate (Pardo et al., 2004). The 


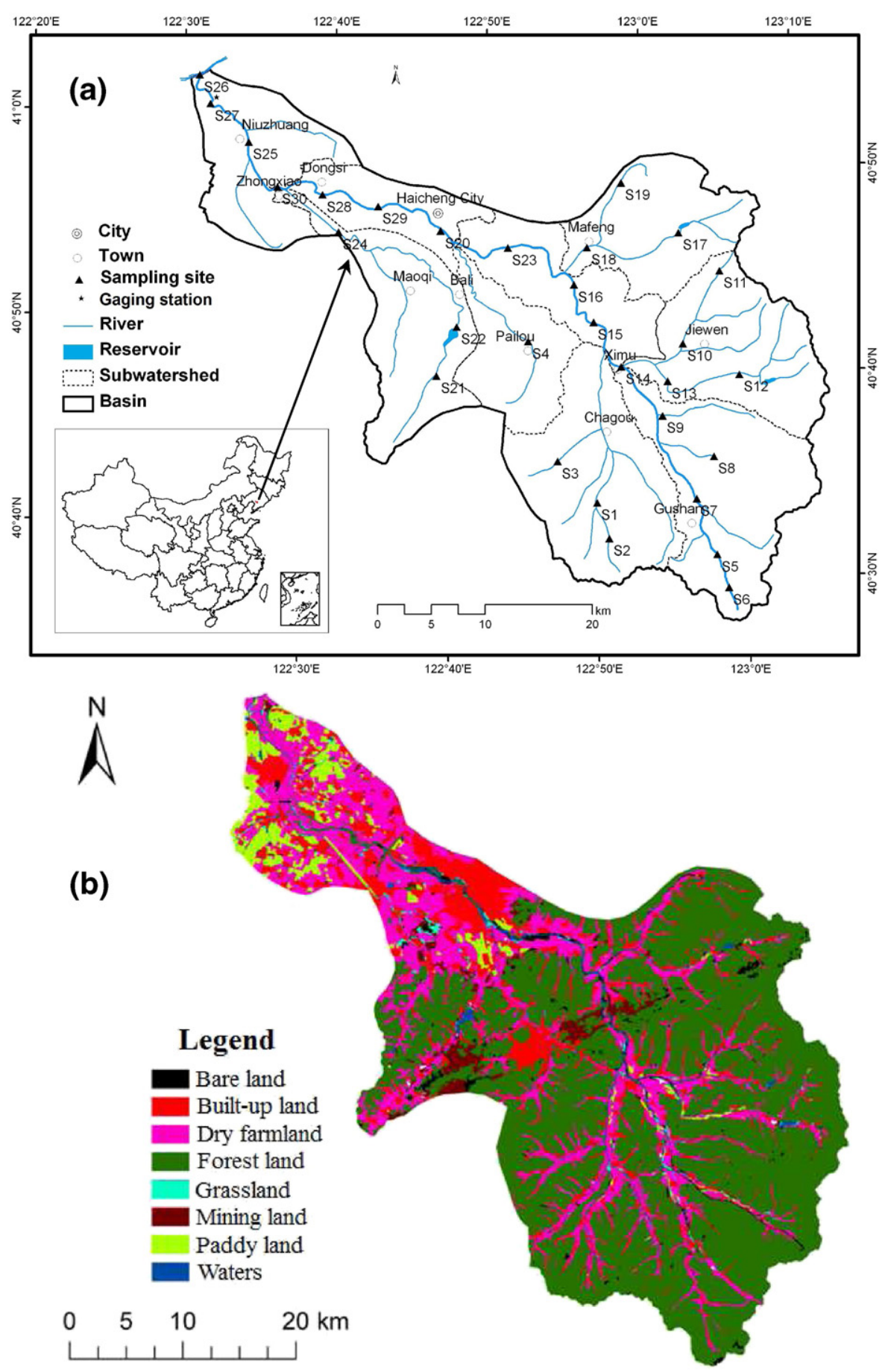

Fig. 1. a) Location of the 30 sampling sites and subwatersheds, and b) land-use patterns in the Haicheng River basin in Northeast China.

pretreated samples were then processed for stable isotope analysis on a VG 253 isotope-ratio mass spectrometer in the Institute of Geology and Geophysics, Chinese Academy of Sciences, Beijing. Stable isotope ratios of $\mathrm{N}-\mathrm{NO}_{3}$ and $\mathrm{O}-\mathrm{NO}_{3}$ are expressed in delta per mil (\%) in accordance with international reference standards and determined by the following equation:

$\delta_{\text {sample }}(\%)=\left[\left(\mathrm{R}_{\text {sample }}-\mathrm{R}_{\text {standard }}\right) / \mathrm{R}_{\text {standard }}\right] \times 1000$

where $R_{\text {sample }}$ and $R_{\text {standard }}$ are the respective ${ }^{15} \mathrm{~N} /{ }^{14} \mathrm{~N}$ or ${ }^{18} \mathrm{O} /{ }^{16} \mathrm{O}$ ratios of the samples and international reference standards. Atmospheric air is defined as an international reference standard for $\delta^{15} \mathrm{~N}$ and Vienna
Standard Mean Ocean Water for $\delta^{18} \mathrm{O}$, each with delta value of $0 \%$. The analytical precision for laboratory analysis was $\pm 0.2 \%$ o for $\delta^{15} \mathrm{~N}$ $\mathrm{NO}_{3}$ and $\pm 0.25 \%$ or for $\delta^{18} \mathrm{O}-\mathrm{NO}_{3}$.

\subsection{Spatial analysis}

Watershed boundaries and land-use maps within the Haicheng River basin were generated from 2009 SPOT imagery ( $2.5 \mathrm{~m}$ resolution) by using ArcGIS version 9.2. Multi-temporal datasets were applied to increase the classification accuracy of land use, to minimize the influence of great temporal variability of individual plots, and to avoid limitations associated with solar illumination and cloud cover. The unsupervised 
classification technique was used when there was no high resolution knowledge about areas and no training sets (Duda and Canty, 2002). Classification was performed on the basis of the dominant land cover (Chang et al., 2002). The land-use types were classified into eight categories in accordance with land-use maps (Fig. 1b). The eight categories were built-up land, managed forest land, grassland, dry farmland, paddy land, mining land, bare land, and waters. Overall accuracy and Kappa coefficients for the classification were $86 \%$ and 0.79 , respectively.

Digital elevation data and stream networks were used to delineate the subwatersheds for each of the 30 sampling sites by using the point coordinates as stream outlets (Mehaffey et al., 2005). On the basis of land-use types in different subwatersheds, the Haicheng River basin was divided into six zones (Fig. 2): forest-farmland (z1), managed forest (z2), farmland-livestock rearing (z3), farmland ( $\mathrm{z} 4)$, residence ( $\mathrm{z5}$ ), and farmland-residence $(\mathrm{z} 6)$. The forest-farmland zone included subwatersheds $1-3,5,7,9,10,13,18$, and 19 . The forest zone was composed of subwatersheds $6,8,11,12$, and 17 . The farmland-livestock rearing zone covered subwatersheds $14-16$ and 22 . Subwatersheds $20,21,23,26$, and 27 belonged to the farmland zone. The residence zone included subwatersheds 4, 24, and 29. Finally, subwatersheds 25,28 , and 30 belonged to the farmland-residence zone. The land-use areas and proportions of land-use types in six zones were also computed using ArcGIS.

To investigate the effects of landscape configuration on in-stream nitrogen pollution, the landscape metrics in six zones were calculated using land-use data by FRAGSTATS 4.2 software. Many indices were redundant with strong correlation, thus they were reduced using principal component analysis by SPSS software. Multicollinearity of these indices was tested by correlation analysis and a reduced set of eight landscape metrics was chosen to characterize landscape shape, diversity, and aggregation. Metrics further described in Table 1 were mean shape index (SHMN), fractal dimension index (FRAC), perimeter area ratio (PARA), contagion (CONTAG), patch richness density (PRD), landscape division index (DIVI), related circumscribing circle (CIRCLE), and Shannon's diversity index (SHDI).

\subsection{Statistical analysis}

Two-way ANOVA with the least significant difference method in post-hoc tests and the Levene statistic for homogeneity of variance test were performed. The purpose of the two-way ANOVA was to understand if there were interactions between different zones and sampling seasons for nitrogen variables in the Haicheng River. For abnormally distributed and unequal-variance variables, nonparametric Dunnett's $C$ test was used in the two-way ANOVA. Correlation analysis using Pearson's correlation coefficients was applied if there were associations between nitrogen variables and land-use patterns at the $p<0.01$ and $p<0.05$ levels (two-tailed). To explain river nitrogen variations at the watershed level, multiple linear regression with a stepwise regression approach based on $p$-value was used to identify significant land-use patterns and eliminate non-significant independent variables from the models (Kang et al., 2010; Bu et al., 2014). These regression equations predicted nitrogen variables from land-use pattern. All statistical analyses were performed using SPSS 13.0.

Source contributions for river nitrate were quantified using threesource mixing model (Phillips and Gregg, 2001) based on dual isotopes of nitrate. For a three-endmember mixture, the source contributions of nitrogen could be estimated from the following mass balance equations:

$\left\{\begin{array}{l}f_{A} \bar{\delta}_{A}+f_{B} \bar{\delta}_{B}+f_{C} \bar{\delta}_{C}=\bar{\delta}_{M} \\ f_{A} \bar{\lambda}_{A}+f_{B} \bar{\lambda}_{B}+f_{C} \bar{\lambda}_{C}=\bar{\lambda}_{M} \\ f_{A}+f_{B}+f_{C}=1\end{array}\right.$

where $\bar{\delta}$ and $\bar{\lambda}$ represent the mean isotopic compositions for two elements of $\mathrm{N}-\mathrm{NO}_{3}$ and $\mathrm{O}-\mathrm{NO}_{3}$, the three nitrogen sources $A, B$, and $C$ and the mixture $M$ are represented by subscripts, and $f_{A}, f_{B}$, and $f_{C}$ are the fractions of $A, B$, and $C$ in $M$.

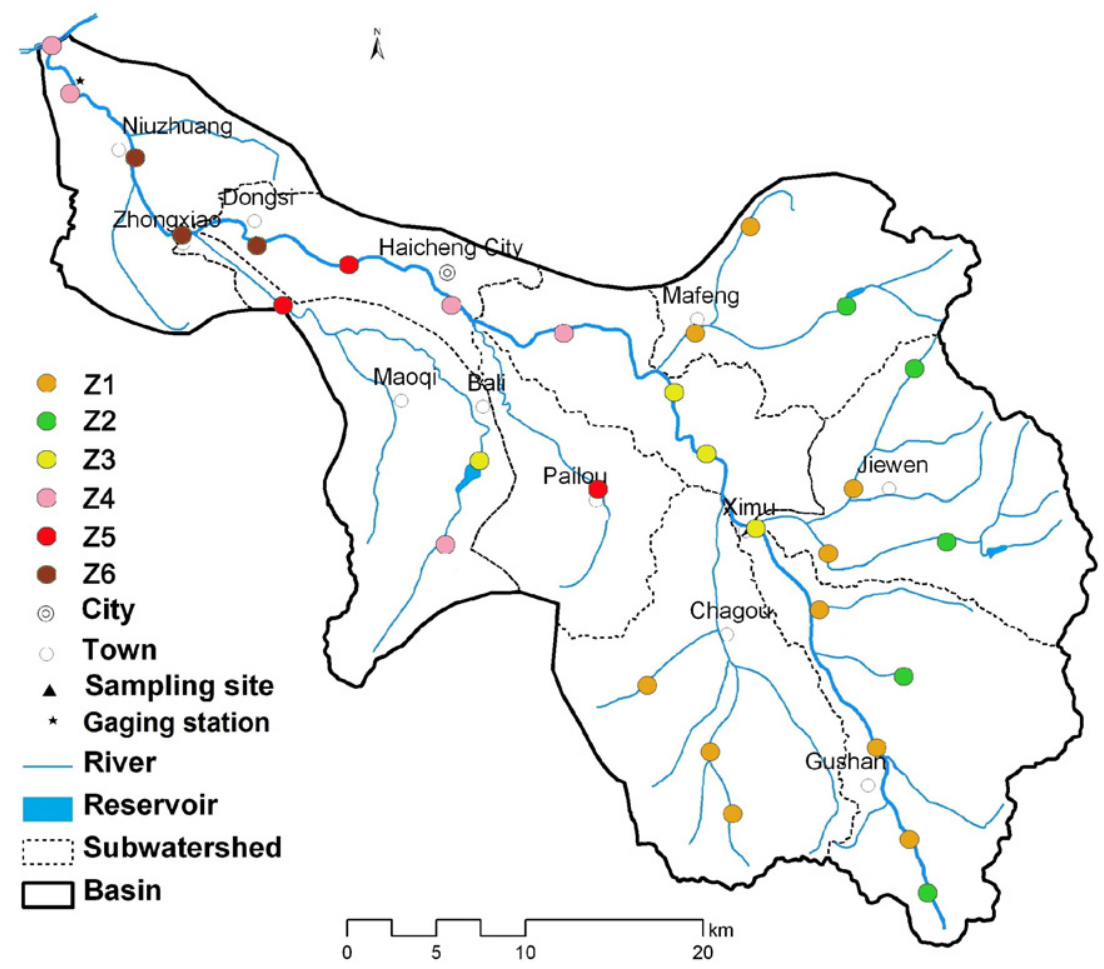

Fig. 2. Six zones based on the land-use types in Haicheng River basin in Northeast China. 
Table 1

Landscape metrics used in the study (McGarigal et al., 2012; Bu et al., 2014).

\begin{tabular}{|c|c|c|}
\hline $\begin{array}{l}\text { Landscape metric } \\
\text { (abbreviation) }\end{array}$ & Description & Calculation \\
\hline Mean shape index (SHMN) & $\begin{array}{l}\text { Mean patch perimeter divided by the minimum perimeter } \\
\text { of the corresponding land use area. }\end{array}$ & $\operatorname{SHAPEMN}=\frac{p_{i j} / \min p_{i j}}{n}$ \\
\hline Fractal dimension index (FRAC) & $\begin{array}{l}2 \text { times the logarithm of patch perimeter }(\mathrm{m}) \text { divided by the } \\
\text { logarithm of patch area }\left(\mathrm{m}^{2}\right)\end{array}$ & $\mathrm{FRAC}=\frac{2 \ln \left(0.25 p_{i j}\right)}{\ln \left(a_{i j}\right)}$ \\
\hline Perimeter area ratio (PARA) & $\begin{array}{l}\text { It is a simple measure of shape complexity and equals the } \\
\text { ratio } \\
\text { of the patch perimeter }(\mathrm{m}) \text { to area }\left(\mathrm{m}^{2}\right) \text {. }\end{array}$ & $\operatorname{PARA}=\frac{p_{i j}}{a_{i j}}$ \\
\hline Contagion (CONTAG) & Tendency of land use types to be aggregated (\%) & CONTAG $=\left[1+\frac{\sum_{i=1}^{m} \sum_{j=1}^{n}\left[\left(p_{i}\right)\left(g_{i k} / \sum_{k=1}^{m} g_{i k}\right)\right]\left[\operatorname{In}\left(p_{i}\right)^{\left(g_{i k} / \sum_{k=1}^{m} g_{i k}\right)}\right]}{2 ! n}\right] \times 100 \%$ \\
\hline Patch richness density (PRD) & The number of patch types per unit area (patches/100 ha) & $\mathrm{PRD}=\frac{m}{A}(10,000)(100)$ \\
\hline Landscape division index (DIVI) & $\begin{array}{l}1 \text { minus the sum of patch area }\left(\mathrm{m}^{2}\right) \text { divided by total } \\
\text { landscape area }\left(\mathrm{m}^{2}\right)\end{array}$ & $\mathrm{DIVI}=\left[1-\sum_{j=1}^{m} \sum_{j=1}^{n}\left(\frac{a_{i j}}{A}\right)^{2}\right]$ \\
\hline $\begin{array}{l}\text { Related circumscribing circle } \\
\quad \text { (CIRCLE) }\end{array}$ & $\begin{array}{l}\text { It equals } 1 \text { minus patch area }\left(\mathrm{m}^{2}\right) \text { divided by the area }\left(\mathrm{m}^{2}\right) \\
\text { of the smallest circumscribing circle. }\end{array}$ & CIRCLE $=1-\frac{a_{i j}}{a_{i j}^{s}}$ \\
\hline Shannon's diversity index (SHDI) & $\begin{array}{l}\text { A popular measure of diversity in community ecology, } \\
\text { indicates } \\
\text { the patch diversity in landscape }\end{array}$ & $\mathrm{SHDI}=-\sum_{i=1}^{m}\left(p_{i} \operatorname{In} p_{i}\right)$ \\
\hline
\end{tabular}

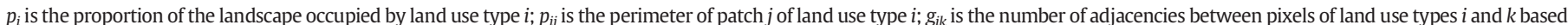

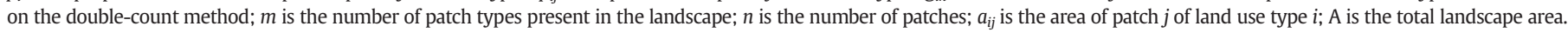

For some cases, a two-source mixing model (Phillips and Gregg, 2001) was used based on similar equations:

$\left\{\begin{array}{l}f_{A} \bar{\delta}_{A}+f_{B} \bar{\delta}_{B}=\bar{\delta}_{M} \\ f_{A}+f_{B}=1\end{array}\right.$

Where $\bar{\delta}_{M}, \bar{\delta}_{A}$, and $\bar{\delta}_{B}$ represent the mean isotopic values (e.g., $\delta^{15} \mathrm{~N}-\mathrm{NO}_{3}$ ) for the mixture $M$ and sources $A$ and $B$, respectively, and $f_{A}$ and $f_{B}$ are the proportions of $A$ and $B$ in $M$.

\section{Results}

\subsection{Spatiotemporal variations of in-stream nitrogen concentrations}

Spatial and seasonal variations of nitrogen variables in six zones are illustrated by box-whisker plots (Fig. 3). According to the two-way ANOVA, only $\mathrm{NH}_{3}-\mathrm{N}$ and $\mathrm{NO}_{2}-\mathrm{N}$ concentrations show significant interaction effects $(p<0.01)$ between different zones and sampling periods. $\mathrm{NO}_{3}-\mathrm{N}$ displays obvious seasonal variations $(p<0.01)$, but no spatial
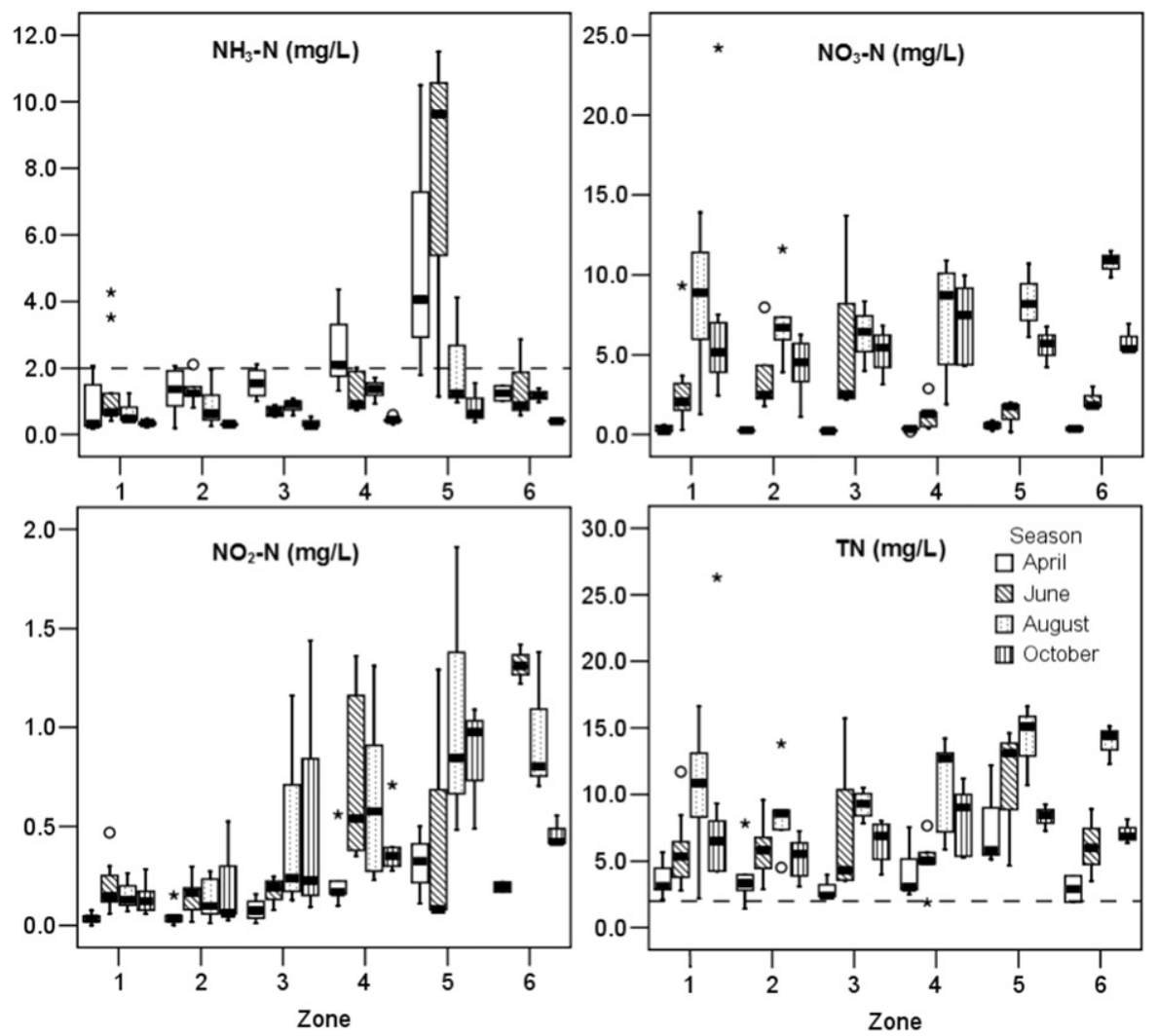

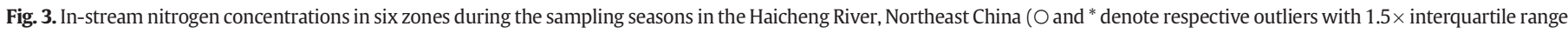

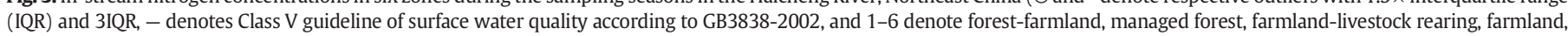
residence, and farmland-residence zones, respectively). 


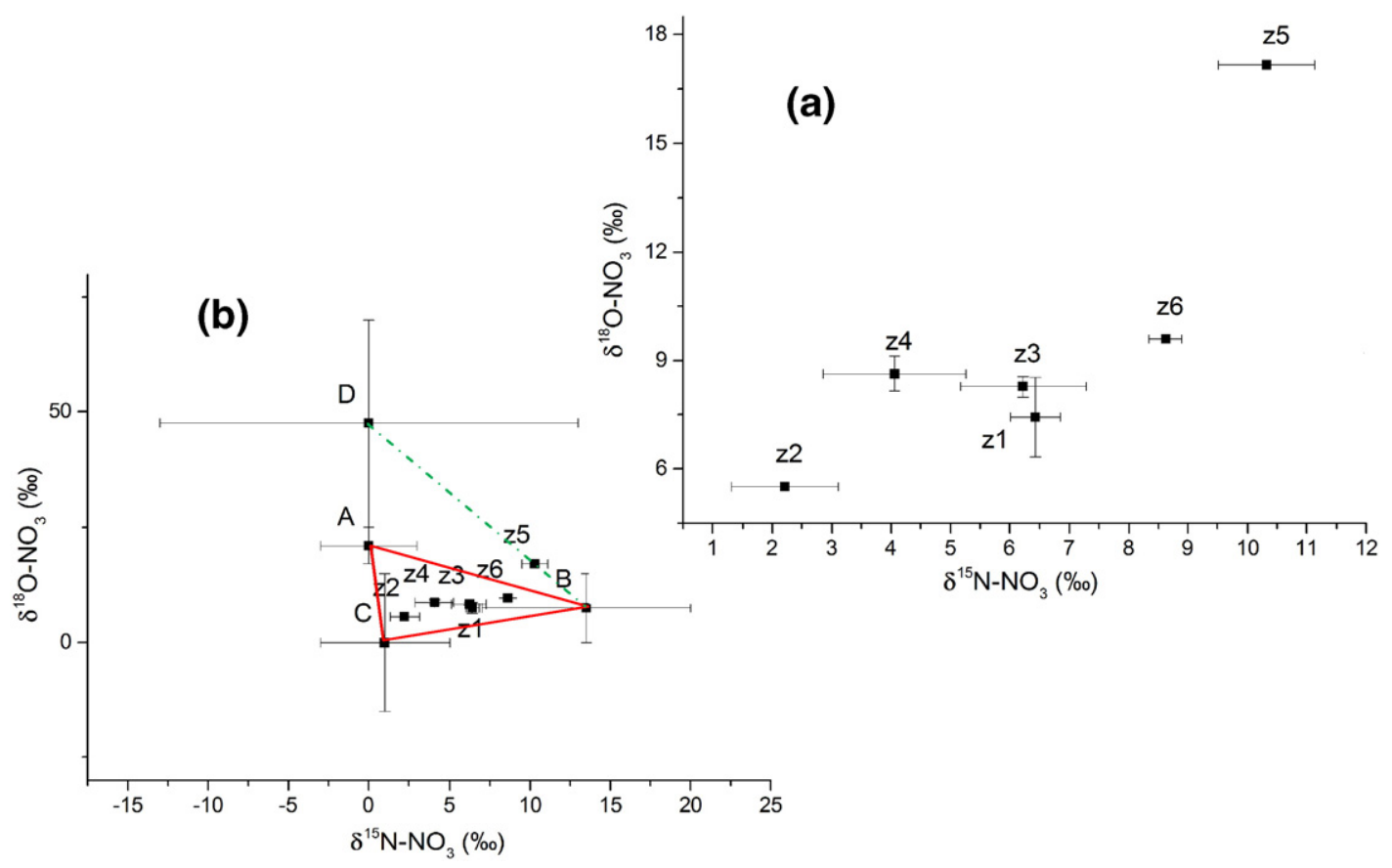

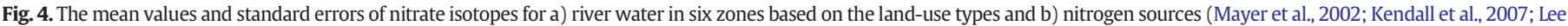

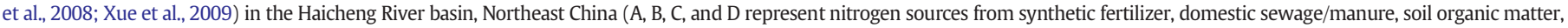
and atmospheric deposition, respectively; z1-z6 denote forest-farmland, managed forest, farmland-livestock rearing, farmland, residence, and farmland-residence zones, respectively).

changes; while TN demonstrates significant spatial $(p<0.05)$ and temporal $(p<0.01)$ trends.

The maximum mean concentration of $7.4 \mathrm{mg} / \mathrm{L} \mathrm{NH}_{3}-\mathrm{N}$ in the Haicheng River is recorded in residence zone in June and the minimum mean value of $0.3 \mathrm{mg} / \mathrm{L}$ is in the managed forest zone in October. The median concentrations of $\mathrm{NH}_{3}-\mathrm{N}$ in farmland zone in April and residence zone in April and June (Fig. 3) all exceed $2.0 \mathrm{mg} / \mathrm{L}$ that is the Class V guideline for $\mathrm{NH}_{3}-\mathrm{N}$ based on the national quality standards for surface waters in China (GB3838-2002). $\mathrm{NO}_{3}-\mathrm{N}$ is the most abundant inorganic form of nitrogen in the Haicheng River, with the highest mean value of $10.8 \mathrm{mg} / \mathrm{L}$ in the farmland-residence zone in August. The concentration of $\mathrm{NO}_{2}-\mathrm{N}$ in the river water has a highest mean value of $1.3 \mathrm{mg} / \mathrm{L}$ in farmland-residence zone in June. In August the TN concentration in the river has a peak mean concentration of $14.1 \mathrm{mg} / \mathrm{L}$ in the residence zone and a second largest value of $13.9 \mathrm{mg} / \mathrm{L}$ in the farmland-residence zone. Median values of TN in the six zones of the river (Fig. 3) always exceed the GB3838-2002 standards for the Class V guideline of $2.0 \mathrm{mg} / \mathrm{L}$.

\subsection{Nitrate isotopic compositions in different zones}

The values of $\delta^{15} \mathrm{~N}-\mathrm{NO}_{3}$ and $\delta^{18} \mathrm{O}-\mathrm{NO}_{3}$ show significant spatial variations $(p<0.05)$ in six zones by the two-way ANOVA but no temporal trends during the sampling seasons. The mean values and standard errors of $\delta^{15} \mathrm{~N}-\mathrm{NO}_{3}$ and $\delta^{18} \mathrm{O}-\mathrm{NO}_{3}$ in the six zones are shown in Fig. 4a. In the forest-farmland zone, the mean values of $\delta^{15} \mathrm{~N}-\mathrm{NO}_{3}$ and $\delta^{18} \mathrm{O}-$ $\mathrm{NO}_{3}$ are $6.4 \pm 0.4 \%$ 。 $($ mean $\pm \mathrm{SE})$ and $7.4 \pm 1.1 \%$. The mean $\delta^{15} \mathrm{~N}-$ $\mathrm{NO}_{3}$ value in the managed forest zone is $2.2 \pm 0.9 \%$ o with the mean $\delta^{18} \mathrm{O}-\mathrm{NO}_{3}$ value of $+5.5 \%$. In the farmland-livestock rearing, farmland, residence, and farmland-residence zones, the mean $\delta^{15} \mathrm{~N}-\mathrm{NO}_{3}$ values are $6.2 \%$, $4.1 \%$, $10.3 \%$, and $8.6 \%$, respectively; while the corresponding $\delta^{18} \mathrm{O}-\mathrm{NO}_{3}$ values are $8.3 \%$, 8.6\%, $17.2 \%$, and $9.6 \%$, respectively. Nitrate in the six zones is composed of mixtures of two or three sources (Fig. 4b).

\subsection{Land-use patterns in different zones}

The proportions of land-use types differ greatly among the six zones in the Haicheng River basin (Fig. 5). Built-up land is $>20 \%$ in residence and farmland-residence zones. Managed forests are widely distributed in the upper and middle reaches of the river basin, ranging from 31.5\% in farmland zone to $89.2 \%$ in forest zone. Minimum value of $5.5 \%$ forests occurs in the farmland-residence zone in the lower reaches of the river. Grassland is dominant along the riparian areas near the agricultural reaches of the river, with $>1.0 \%$ cover in farmland, residence, and farmland-residence zones. Dry farmland and paddy land are mainly centralized in the middle and lower reaches of the river and their covers are $>40 \%$ in farmland and farmland-residence zones. Additionally, the

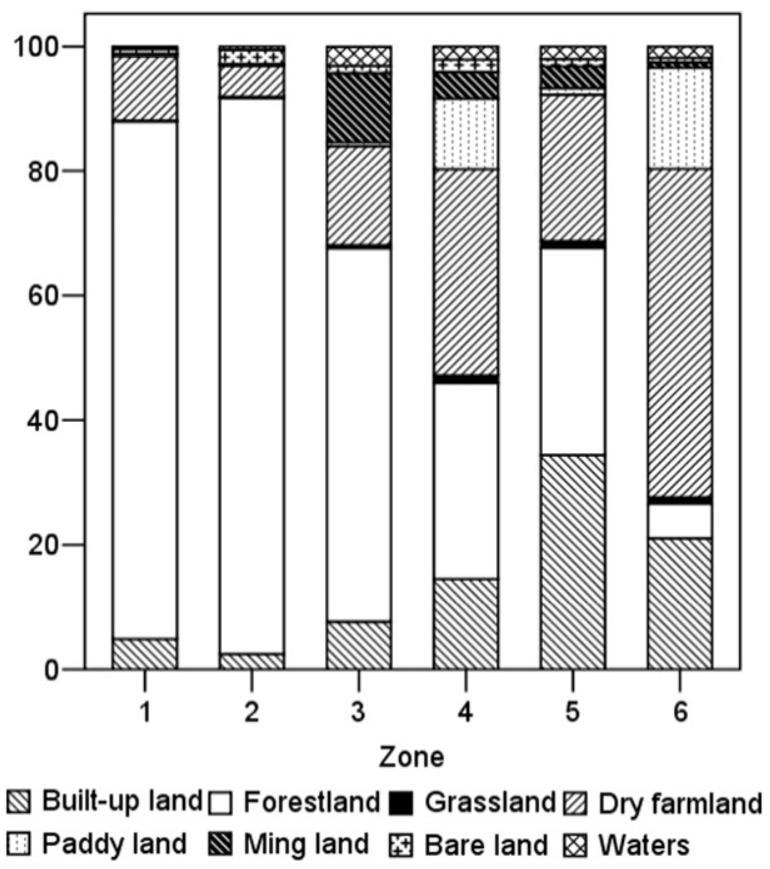

Fig. 5. Composition (\%) of land-use types in different zones in the Haicheng River basin, Northeast China (1-6 denote forest-farmland, managed forest, farmland-livestock rearing, farmland, residence, and farmland-residence zones, respectively). 

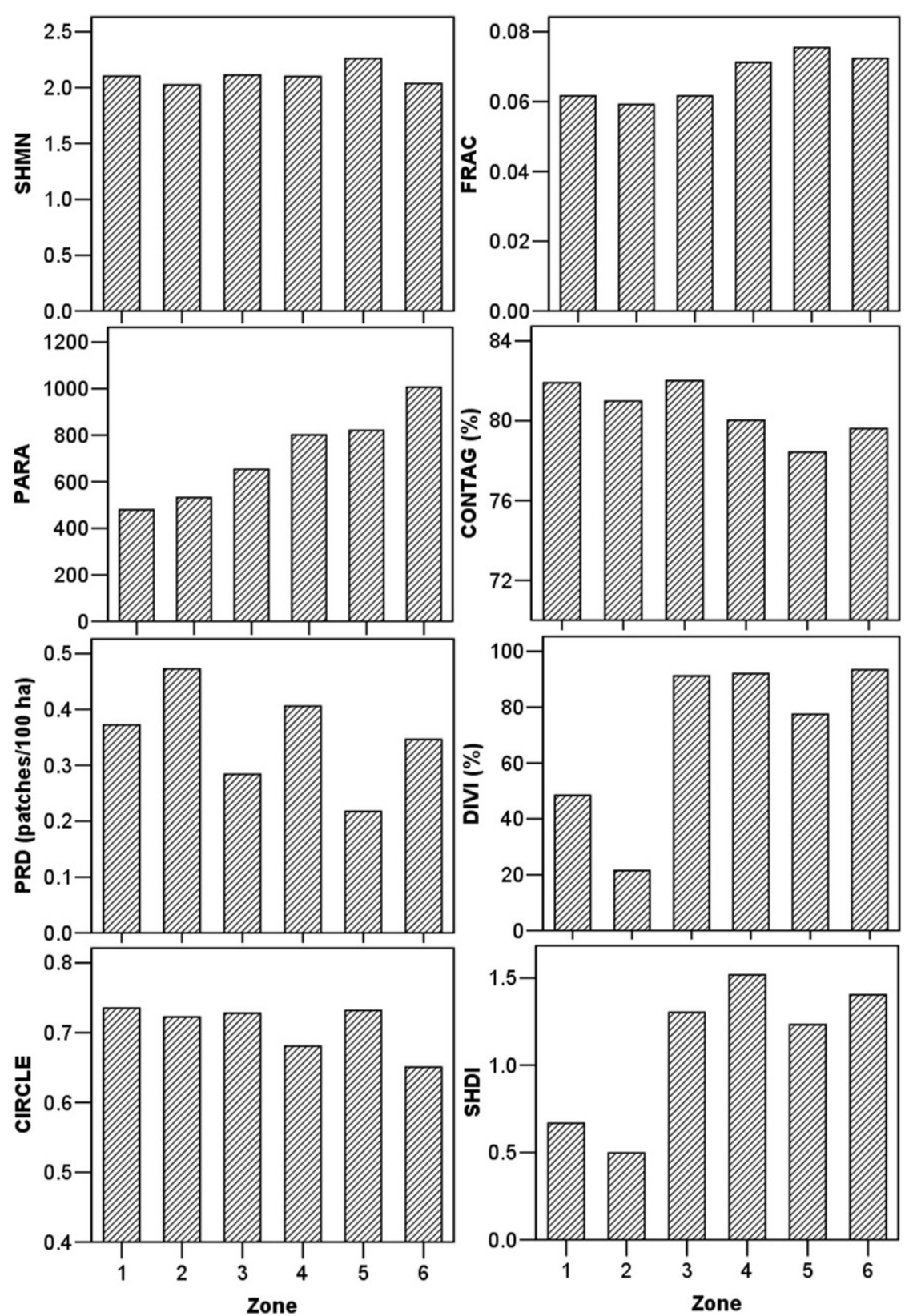

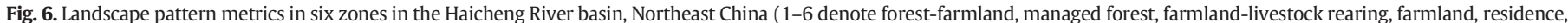
and farmland-residence zones, respectively).

proportions of dry farmland and paddy land reach maxima of $52.7 \%$ and $16.3 \%$ in the farmland-residence zone. Mining land is mainly distributed in farmland-livestock rearing zone where its maximum proportion is $11.1 \%$. The proportions of bare land and waters range from $0.7 \%$ in the farmland-residence zone to $2.3 \%$ in the managed forest zone and from $0.4 \%$ in the forest-farmland zone to $3.1 \%$ in the farmland-livestock rearing zone.

Landscape metrics also show large variations in the six zones (Fig. 6). The maximum values of SHMN (2.26) and FRAC (0.075) occur in the residence zone, and their minimum values (2.02 and 0.059 ) are obtained in the managed forest zone. The maxima of PARA (1006) and DIVI (93.4\%) and the minimum value of CIRCLE (0.65) are all found in the farmland-residence zone. The lowest values of CONTAG (78.4\%) and PRD ( 0.22 patches $/ 100$ ha) are recorded in the residence zone. The values of SHDI range from 0.50 in the managed forest zone to 1.52 in the farmland zone. Additionally, the smallest value of PARA (479) and the largest value of CIRCLE (0.74) are observed in the forest-farmland zone.

\subsection{Relationships between land-use types and in-stream nitrogen}

Correlation analysis shows several significant relationships between land-use types and nitrogen variables in the Haicheng River basin during the sampling seasons (Table 2). In April, the proportions of builtup land in different zones are significantly correlated with $\mathrm{NO}_{3}-\mathrm{N}$ $(p<0.05), \mathrm{NO}_{2}-\mathrm{N}(p<0.01)$, and $\mathrm{NH}_{3}-\mathrm{N}(p<0.05)$. Grassland proportions are also linked with $\mathrm{NO}_{2}-\mathrm{N}(p<0.05)$. In June, built-up land use is only correlated with $\mathrm{NH}_{3}-\mathrm{N}(p<0.05)$ and forestland use is related with $\mathrm{NO}_{2}-\mathrm{N}(p<0.05)$. As agricultural land uses, dry farmland and paddy land uses are all associated with $\mathrm{NO}_{2}-\mathrm{N}(p<0.01)$, and paddy land with $\delta{ }^{15} \mathrm{~N}^{-\mathrm{NO}_{3}}(p<0.05)$. In August, built-up land use shows significant correlations with $\mathrm{NO}_{2}-\mathrm{N}, \mathrm{NH}_{3}-\mathrm{N}, \delta^{18} \mathrm{O}-\mathrm{NO}_{3}(p<0.01)$, and TN 
Table 2

Pearson's correlation coefficients between land-use types and nitrogen variables during different seasons in the Haicheng River basin, China.

\begin{tabular}{|c|c|c|c|c|c|c|}
\hline & $\mathrm{NO}_{3}-\mathrm{N}$ & $\mathrm{NO}_{2}-\mathrm{N}$ & $\mathrm{NH}_{3}-\mathrm{N}$ & $\mathrm{TN}$ & $\delta^{15} \mathrm{~N}-\mathrm{NO}_{3}$ & $\delta^{18} \mathrm{O}-\mathrm{NO}_{3}$ \\
\hline \multicolumn{7}{|l|}{ April } \\
\hline Built-up land & $0.901^{*}$ & $0.921^{* *}$ & $0.833^{*}$ & 0.728 & 0.928 & n.a. \\
\hline Forestland & -0.470 & -0.798 & -0.385 & -0.163 & -0.940 & n.a. \\
\hline Grassland & 0.543 & $0.895^{*}$ & 0.513 & 0.308 & 0.879 & n.a. \\
\hline Dry farmland & 0.291 & 0.629 & 0.127 & -0.067 & 0.986 & n.a. \\
\hline Paddy land & 0.036 & 0.438 & -0.127 & -0.282 & 0.977 & n.a. \\
\hline Mining land & -0.198 & 0.054 & 0.162 & -0.107 & 0.902 & n.a. \\
\hline Bare land & -0.306 & -0.039 & 0.042 & 0.063 & -0.639 & n.a. \\
\hline Waters & 0.075 & 0.476 & 0.34 & 0.003 & 0.869 & n.a. \\
\hline \multicolumn{7}{|l|}{ June } \\
\hline Built-up land & -0.673 & 0.522 & $0.835^{*}$ & 0.757 & 0.934 & n.a. \\
\hline Forestland & 0.564 & $-0.907^{*}$ & -0.269 & -0.206 & -0.883 & n.a. \\
\hline Grassland & -0.712 & 0.694 & 0.453 & 0.309 & 0.872 & n.a. \\
\hline Dry farmland & -0.506 & $0.983^{* *}$ & 0.030 & -0.045 & 0.919 & n.a. \\
\hline Paddy land & -0.487 & $0.949^{* *}$ & -0.235 & -0.376 & $0.956^{*}$ & n.a. \\
\hline Mining land & 0.499 & -0.217 & -0.083 & 0.190 & 0.101 & n.a. \\
\hline Bare land & 0.093 & -0.345 & -0.103 & -0.207 & -0.579 & n.a. \\
\hline Waters & 0.120 & 0.246 & 0.086 & 0.268 & 0.346 & n.a. \\
\hline \multicolumn{7}{|l|}{ August } \\
\hline Built-up land & 0.424 & $0.948^{* *}$ & $0.933^{* *}$ & $0.898^{*}$ & 0.809 & $0.949^{* *}$ \\
\hline Forestland & -0.554 & $-0.914^{*}$ & -0.598 & -0.784 & -0.668 & -0.541 \\
\hline Grassland & 0.237 & $0.882^{*}$ & 0.803 & 0.664 & 0.558 & 0.654 \\
\hline Dry farmland & 0.683 & 0.768 & 0.359 & 0.711 & 0.548 & 0.301 \\
\hline Paddy land & 0.580 & 0.530 & 0.148 & 0.464 & 0.239 & -0.005 \\
\hline Mining land & -0.590 & 0.120 & 0.055 & -0.235 & 0.154 & 0.129 \\
\hline Bare land & -0.647 & -0.341 & 0.028 & -0.586 & -0.787 & -0.311 \\
\hline Waters & -0.267 & 0.547 & 0.376 & 0.165 & 0.410 & 0.378 \\
\hline \multicolumn{7}{|l|}{ October } \\
\hline Built-up land & 0.106 & $0.901^{*}$ & $0.916^{*}$ & 0.522 & 0.748 & $0.948^{* *}$ \\
\hline Forestland & -0.281 & -0.632 & -0.446 & -0.401 & -0.483 & -0.538 \\
\hline Grassland & 0.301 & 0.759 & 0.676 & 0.517 & 0.365 & 0.691 \\
\hline Dry farmland & 0.333 & 0.374 & 0.195 & 0.319 & 0.344 & 0.294 \\
\hline Paddy land & 0.346 & 0.078 & -0.067 & 0.187 & 0.042 & -0.004 \\
\hline Mining land & -0.052 & 0.404 & 0.010 & -0.039 & 0.093 & 0.111 \\
\hline Bare land & -0.279 & -0.199 & -0.124 & -0.374 & -0.776 & -0.317 \\
\hline Waters & -0.031 & 0.682 & 0.257 & 0.080 & 0.367 & 0.384 \\
\hline
\end{tabular}

* $p<0.05$ (2-tailed)

** $p<0.01$ (2-tailed).

$(p<0.05)$. Forestland and grassland are significantly related to $\mathrm{NO}_{2}-\mathrm{N}$ $(p<0.05)$. Although dry farmland and paddy land have high correlation coefficients with $\mathrm{NO}_{3}-\mathrm{N}, \mathrm{NO}_{2}-\mathrm{N}$, and $\mathrm{TN}$, they are statistically nonsignificant $(p>0.05)$. In October, built-up land use has significant relations with $\mathrm{NO}_{2}-\mathrm{N}$ and $\mathrm{NH}_{3}-\mathrm{N}(p<0.05)$, and $\delta^{18} \mathrm{O}-\mathrm{NO}_{3}(p<0.01)$. The correlation coefficients between grassland and nitrogen variables are very high, but they are not statistically significant $(p>0.05)$.

These correlations are further investigated with stepwise multiple regression models that also show several strong relationships with $\mathrm{R}^{2}$ values $>0.6$ between land-use types and nitrogen variables in different seasons (Table 3). In April, nitrogen variables of $\mathrm{NO}_{3}-\mathrm{N}, \mathrm{NO}_{2}-\mathrm{N}$, and $\mathrm{NH}_{3}-\mathrm{N}$ are respectively predicted by the proportions of built-up land use. In June, $\mathrm{NO}_{2}-\mathrm{N}$ is defined by dry farmland and mining land uses, $\mathrm{NH}_{3}-\mathrm{N}$ by built-up land and forestland uses, and $\delta^{15} \mathrm{~N}-\mathrm{NO}_{3}$ by paddy land use combined with forestland use. In August, TN is only estimated based on built-up land. Whether in August or October, $\mathrm{NO}_{2}-\mathrm{N}, \mathrm{NH}_{3}-\mathrm{N}$, and $\delta^{18} \mathrm{O}-\mathrm{NO}_{3}$ are all explained by built-up land use and another landuse type.

\subsection{Relationships between landscape metrics and in-stream nitrogen}

The correlations between landscape metrics and nitrogen variables are also significant during the sampling seasons (Table 4). In April, the shape metric of SHMN is significantly related with $\mathrm{NO}_{2}-\mathrm{N}$ $(p<0.01), \mathrm{NH}_{3}-\mathrm{N}(p<0.05)$, and TN $(p<0.05)$. FRAC, as one of the
Table 3

Stepwise multiple regression models for land-use types and nitrogen variables during different seasons in the Haicheng River basin, China.

\begin{tabular}{|c|c|c|c|c|c|}
\hline Parameter & $\begin{array}{l}\text { Independent } \\
\text { variable }\end{array}$ & Regression equations & $\mathrm{R}^{2}$ & $\begin{array}{l}\text { Adjusted } \\
\mathrm{R}^{2}\end{array}$ & Sig. \\
\hline \multicolumn{6}{|l|}{ April } \\
\hline $\mathrm{NO}_{3}-\mathrm{N}$ & Built-up land & $0.219+0.009 \mathrm{BUI}$ & 0.812 & 0.765 & 0.014 \\
\hline $\mathrm{NO}_{2}-\mathrm{N}$ & Built-up land & $0.029+0.009 \mathrm{BUI}$ & 0.849 & 0.811 & 0.009 \\
\hline $\mathrm{NH}_{3}-\mathrm{N}$ & Built-up land & $0.436+0.119 \mathrm{BUI}$ & 0.695 & 0.618 & 0.039 \\
\hline \multicolumn{6}{|l|}{ June } \\
\hline $\mathrm{NO}_{2}-\mathrm{N}$ & $\begin{array}{l}\text { Dry farmland, } \\
\text { mining land }\end{array}$ & $\begin{array}{l}-0.024+0.025 \mathrm{DRY} \\
-0.019 \mathrm{MIN}\end{array}$ & 0.995 & 0.991 & $<0.001$ \\
\hline $\mathrm{NH}_{3}-\mathrm{N}$ & $\begin{array}{l}\text { Built-up land, } \\
\text { forestland }\end{array}$ & $\begin{array}{l}-5.398+0.310 \mathrm{BUI}+ \\
0.065 \mathrm{FOR}\end{array}$ & 0.997 & 0.995 & $<0.001$ \\
\hline$\delta^{15} \mathrm{~N}-\mathrm{NO}_{3}$ & $\begin{array}{l}\text { Paddy land, } \\
\text { forestland }\end{array}$ & $\begin{array}{l}-46.522+ \\
44.635 \mathrm{PAD}+ \\
0.376 \mathrm{FOR}\end{array}$ & 1.000 & 1.000 & 0.001 \\
\hline \multicolumn{6}{|l|}{ August } \\
\hline $\mathrm{NO}_{2}-\mathrm{N}$ & $\begin{array}{l}\text { Built-up land, } \\
\text { forestland }\end{array}$ & $\begin{array}{l}0.570+0.020 \mathrm{BUI}- \\
0.006 \mathrm{FOR}\end{array}$ & 0.991 & 0.984 & 0.001 \\
\hline $\mathrm{NH}_{3}-\mathrm{N}$ & $\begin{array}{l}\text { Built-up land, } \\
\text { bare land }\end{array}$ & $\begin{array}{l}0.135+0.046 \mathrm{BUI}+ \\
0.293 \mathrm{BAR}\end{array}$ & 0.984 & 0.974 & 0.002 \\
\hline TN & Built-up land & $8.715+0.175 \mathrm{BUI}$ & 0.806 & 0.758 & 0.015 \\
\hline$\delta^{18} \mathrm{O}-\mathrm{NO}_{3}$ & $\begin{array}{l}\text { Built-up land, } \\
\text { paddy land }\end{array}$ & $\begin{array}{l}5.343+0.351 \mathrm{BUI}- \\
0.180 \mathrm{PAD}\end{array}$ & 0.991 & 0.984 & 0.001 \\
\hline \multicolumn{6}{|l|}{ October } \\
\hline $\mathrm{NO}_{2}-\mathrm{N}$ & $\begin{array}{l}\text { Built-up land, } \\
\text { mining land }\end{array}$ & $\begin{array}{l}0.078+0.019 \mathrm{BUI}+ \\
0.023 \mathrm{MIN}\end{array}$ & 0.963 & 0.938 & 0.007 \\
\hline $\mathrm{NH}_{3}-\mathrm{N}$ & $\begin{array}{l}\text { Built-up land, } \\
\text { dry farmland }\end{array}$ & $\begin{array}{l}0.287+0.020 \mathrm{BUI}- \\
0.005 \mathrm{DRY}\end{array}$ & 0.984 & 0.973 & 0.002 \\
\hline$\delta^{18} \mathrm{O}-\mathrm{NO}_{3}$ & $\begin{array}{l}\text { Built-up land, } \\
\text { paddy land }\end{array}$ & $\begin{array}{l}5.455+0.348 \mathrm{BUI}- \\
0.189 \mathrm{PAD}\end{array}$ & 0.988 & 0.980 & 0.001 \\
\hline
\end{tabular}

composition and configuration indices, is significantly correlated with $\mathrm{NO}_{3}-\mathrm{N}(p<0.05), \mathrm{NO}_{2}-\mathrm{N}(p<0.01), \mathrm{NH}_{3}-\mathrm{N}(p<0.05)$, and $\delta^{15} \mathrm{~N}-\mathrm{NO}_{3}(p<0.05)$. PARA also has significant correlations with $\mathrm{NO}_{2}-\mathrm{N}(p<0.05), \mathrm{NH}_{3}-\mathrm{N}(p<0.01)$, and TN $(p<0.01)$. CONTAG is linked with $\mathrm{NH}_{3}-\mathrm{N}(p<0.05)$ and TN $(p<0.01)$. PRD and DIVI are associated with $\delta^{15} \mathrm{~N}-\mathrm{NO}_{3}(p<0.05)$. In June, SHMN has significant correlations with all nitrogen variables $(p<0.01$ or $p<0.05)$ except for $\mathrm{NO}_{3}-\mathrm{N}$ and $\delta^{18} \mathrm{O}-\mathrm{NO}_{3}$. FRAC only relates with $\delta^{15} \mathrm{~N}-\mathrm{NO}_{3}(p<0.05)$, and PARA with $\mathrm{NO}_{2}-\mathrm{N}(p<0.05)$. PRD correlates with TN $(p<0.01)$, and CIRCLE with $\mathrm{NO}_{2}-\mathrm{N}(p<0.05)$. In August, SHMN only has significant correlations with $\delta^{15} \mathrm{~N}-\mathrm{NO}_{3}(p<0.05)$. FRAC, PARA, and CONTAG all strongly relate with $\mathrm{NO}_{2}-\mathrm{N}, \mathrm{NH}_{3}-\mathrm{N}$, and TN $(p<0.05$ or $p<0.01)$. PRD associates with nitrate isotopes $(p<0.05)$. In October, SHMN is linked with $\mathrm{NH}_{3}-\mathrm{N}$ and $\delta^{18} \mathrm{O}-\mathrm{NO}_{3}(p<0.05)$, and PARA with $\mathrm{NO}_{2}-\mathrm{N}(p<0.05)$. Additionally, CONTAG correlates with $\mathrm{NH}_{3}-\mathrm{N}(p<0.05)$, and PRD with $\mathrm{NO}_{2}-\mathrm{N}$ and nitrate isotopes $(p<0.05)$.

The regression analysis results between landscape metrics and nitrogen variables also display good fitness during different seasons (Table 5). In April, landscape metrics of FRAC, PARA, PRD, and CONTAG predict all nitrogen variables except for $\delta^{18} \mathrm{O}-\mathrm{NO}_{3}$. In June, $\mathrm{NO}_{2}-\mathrm{N}$ is only estimated by CIRCLE, while $\mathrm{NH}_{3}-\mathrm{N}, \mathrm{TN}$, and $\delta^{15} \mathrm{~N}-\mathrm{NO}_{3}$ are all explained by SHMN. Additionally, landscape metrics account for $74.0 \%\left(\delta^{15} \mathrm{~N}-\mathrm{NO}_{3}\right)$ to $96.9 \%$ $\left(\mathrm{NH}_{3}-\mathrm{N}\right)$ of the variances of nitrogen variables in August and $70.9 \%$ $\left(\mathrm{NO}_{2}-\mathrm{N}\right)$ to $99.0 \%\left(\mathrm{NH}_{3}-\mathrm{N}\right)$ of the variances in October.

\subsection{Nitrogen sources and their contributions in six zones}

Most $\delta^{18} \mathrm{O}-\mathrm{NO}_{3}$ values are $<+15 \%$ in riverine nitrate, indicating that atmospheric nitrate makes minimal contribution to surface runoff (Mayer et al., 2002). An exception is that the mean $\delta^{18} \mathrm{O}-\mathrm{NO}_{3}$ value in $\mathrm{z} 5$ is higher (17.2\%) and located on a line between domestic sewage/ manure and atmospheric deposition (Fig. 4b). The mean proportions 
Table 4

Pearson's correlation coefficients between landscape metrics and nitrogen variables during different seasons in the Haicheng River basin, China.

\begin{tabular}{|c|c|c|c|c|c|c|}
\hline & $\mathrm{NO}_{3}-\mathrm{N}$ & $\mathrm{NO}_{2}-\mathrm{N}$ & $\mathrm{NH}_{3}-\mathrm{N}$ & TN & $\delta^{15} \mathrm{~N}-\mathrm{NO}_{3}$ & $\delta^{18} \mathrm{O}-\mathrm{NO}_{3}$ \\
\hline \multicolumn{7}{|l|}{ April } \\
\hline SHMN $^{\mathrm{a}}$ & 0.772 & $0.948^{* * *}$ & $0.866^{*}$ & $0.848^{*}$ & 0.993 & n.a. \\
\hline FRAC $^{\mathrm{b}}$ & $0.862^{*}$ & $0.975^{* *}$ & $0.866^{*}$ & 0.759 & $0.999^{*}$ & n.a. \\
\hline PARA $^{\mathrm{C}}$ & 0.758 & $0.909^{*}$ & $0.927^{* *}$ & $0.929^{* *}$ & 0.790 & n.a. \\
\hline CONTAG $^{\mathrm{d}}$ & -0.736 & -0.702 & $-0.917^{*}$ & $-0.934^{* *}$ & -0.760 & n.a. \\
\hline $\mathrm{PRD}^{\mathrm{e}}$ & -0.644 & -0.528 & -0.625 & -0.478 & $-0.999^{*}$ & n.a. \\
\hline $\mathrm{DIVI}^{\mathrm{f}}$ & 0.243 & 0.599 & 0.281 & -0.019 & 0.999* & n.a. \\
\hline CIRCLE $^{\mathrm{g}}$ & 0.058 & -0.369 & 0.190 & 0.345 & 0.656 & n.a. \\
\hline $\mathrm{SHDI}^{\mathrm{h}}$ & 0.278 & 0.708 & 0.367 & 0.063 & 0.974 & n.a. \\
\hline \multicolumn{7}{|l|}{ June } \\
\hline SHMN $^{\mathrm{a}}$ & 0.157 & $0.935^{* * *}$ & $0.867^{*}$ & $0.865^{*}$ & $0.988^{*}$ & n.a. \\
\hline FRAC $^{\mathrm{b}}$ & -0.809 & 0.725 & 0.632 & 0.479 & $0.955^{*}$ & n.a. \\
\hline PARA $^{\mathrm{C}}$ & -0.513 & $0.913^{*}$ & 0.275 & 0.227 & 0.786 & n.a. \\
\hline CONTAG $^{\mathrm{d}}$ & 0.783 & -0.593 & -0.761 & -0.582 & -0.750 & n.a. \\
\hline PRD $^{\mathrm{e}}$ & 0.106 & -0.072 & -0.666 & $-0.825^{*}$ & -0.874 & n.a. \\
\hline $\mathrm{DIVI}^{\mathrm{f}}$ & -0.232 & 0.612 & 0.074 & 0.144 & 0.599 & n.a. \\
\hline CIRCLE $^{\mathrm{g}}$ & 0.383 & $-0.937^{* *}$ & 0.293 & 0.406 & 0.662 & n.a. \\
\hline $\mathrm{SHDI}^{\mathrm{h}}$ & -0.335 & 0.658 & 0.120 & 0.137 & 0.636 & n.a. \\
\hline \multicolumn{7}{|l|}{ August } \\
\hline SHMN $^{\mathrm{a}}$ & -0.111 & 0.520 & 0.756 & 0.479 & 0.672 & $0.889^{*}$ \\
\hline FRAC $^{\mathrm{b}}$ & 0.494 & $0.952^{* *}$ & $0.855^{*}$ & $0.883^{*}$ & 0.749 & 0.800 \\
\hline PARA $^{\mathrm{C}}$ & 0.516 & $0.905^{*}$ & $0.884^{*}$ & $0.853^{*}$ & 0.577 & 0.763 \\
\hline CONTAG $^{\mathrm{d}}$ & -0.435 & $-0.871^{*}$ & $-0.922^{* *}$ & $-0.812^{*}$ & -0.537 & -0.793 \\
\hline PRD $^{\mathrm{e}}$ & -0.115 & -0.653 & -0.595 & -0.599 & $-0.860^{*}$ & $-0.835^{*}$ \\
\hline DIVI $^{\mathrm{f}}$ & 0.183 & 0.717 & 0.388 & 0.492 & 0.665 & 0.430 \\
\hline CIRCLE $^{g}$ & -0.577 & -0.479 & -0.084 & -0.406 & -0.144 & 0.084 \\
\hline $\mathrm{SHDI}^{\mathrm{h}}$ & 0.138 & 0.766 & 0.496 & 0.488 & 0.581 & 0.450 \\
\hline \multicolumn{7}{|l|}{ October } \\
\hline SHMN $^{\mathrm{a}}$ & 0.178 & 0.785 & $0.888^{*}$ & 0.630 & 0.624 & $0.895^{*}$ \\
\hline FRAC $^{\mathrm{b}}$ & 0.335 & 0.768 & 0.771 & 0.619 & 0.537 & 0.795 \\
\hline PARA $^{\mathrm{c}}$ & 0.125 & $0.843^{*}$ & 0.429 & 0.258 & 0.459 & 0.508 \\
\hline CONTAG $^{\mathrm{d}}$ & -0.005 & -0.740 & $-0.829^{*}$ & -0.372 & -0.463 & -0.784 \\
\hline PRD $^{\mathrm{e}}$ & -0.100 & $-0.842^{*}$ & -0.709 & -0.489 & $-0.883^{*}$ & $-0.838^{*}$ \\
\hline DIVI $^{\mathrm{f}}$ & 0.407 & 0.606 & 0.277 & 0.442 & 0.408 & 0.422 \\
\hline CIRCLE $^{\mathrm{g}}$ & -0.214 & -0.033 & 0.146 & -0.020 & 0.055 & 0.096 \\
\hline $\mathrm{SHDI}^{\mathrm{h}}$ & 0.346 & 0.642 & 0.334 & 0.398 & 0.306 & 0.438 \\
\hline
\end{tabular}

a Mean shape index.

b Fractal dimension index.

c Perimeter area ratio.

d Contagion.

e Patch richness density.

${ }^{f}$ Landscape division index.

g Related circumscribing circle.

h Shannon's diversity index.

* $p<0.05$ (2-tailed).

** $p<0.01$ (2-tailed)

of these two sources in $\mathrm{z} 5$ are determined based on Eq.3 using $\delta^{15} \mathrm{~N}$ $\mathrm{NO}_{3}$ values (Table 6). Atmospheric deposition shows $23.6 \pm 6.0 \%$ of the contribution to river nitrogen, and domestic sewage/manure has the largest contribution of $76.4 \pm 6.0 \%$ in $\mathrm{z} 5$.

Based on the isotopic compositions of nitrate in different nitrogen sources and six zones (Fig. $4 \mathrm{~b}$ ), the average $\delta^{15} \mathrm{~N}-\mathrm{NO}_{3}$ and $\delta^{18} \mathrm{O}-\mathrm{NO}_{3}$ values for most zones (except $\mathrm{z} 5$ ) are in the mixing triangle defined by the endmember sources from synthetic fertilizer, domestic sewage/ manure, and soil organic matter. Therefore, the principal nitrogen sources in river nitrate for $\mathrm{z} 1-\mathrm{z} 4$ and $\mathrm{z} 6$ are regarded as a mixture of the three sources and their contributions are calculated according to Eq.(2) (Table 6). The contributions of synthetic fertilizer to the river nitrogen pollution in the above five zones are in a narrow range from $19.3 \pm 5.2 \%(z 1)$ to $31.5 \pm 4.2 \%(z 4)$. Domestic sewage/manure is a major contributor to river nitrogen in the river basin, with a large contribution of $62.8 \pm 2.1 \%$ in $z 6$. The proportions of manure are $45.0 \pm$ $3.3 \%$ in $z 1,11.5 \pm 7.0 \%$ in $z 2,43.7 \pm 8.3 \%$ in $z 3$, and $27.0 \pm 9.9 \%$ in $z 4$. Soil organic matter mainly contributes $66.4 \pm 4.5 \%$ and $41.5 \pm 6.8 \%$ to z2 and z4, respectively.
Table 5

Stepwise multiple regression models for landscape metrics and nitrogen variables during different seasons in the Haicheng River basin, China.

\begin{tabular}{|c|c|c|c|c|c|}
\hline Parameter & $\begin{array}{l}\text { Independent } \\
\text { variable }\end{array}$ & Regression equations & $\mathrm{R}^{2}$ & $\begin{array}{l}\text { Adjusted } \\
\mathrm{R}^{2}\end{array}$ & Sig. \\
\hline \multicolumn{6}{|l|}{ April } \\
\hline $\mathrm{NO}_{3}-\mathrm{N}$ & FRAC $^{\mathrm{a}}$ & $-0.698+15.794$ FRAC & 0.743 & 0.678 & 0.027 \\
\hline $\mathrm{NO}_{2}-\mathrm{N}$ & FRAC $^{\mathrm{a}}$ & $-1.019+0.200 \mathrm{FRAC}$ & 0.966 & 0.957 & $<0.001$ \\
\hline $\mathrm{NH}_{3}-\mathrm{N}$ & PARA $^{\mathrm{b}}, \mathrm{PRD}^{\mathrm{c}}$ & $\begin{array}{l}-11.014+0.023 \text { PARA }- \\
\text { 7.107PRD }\end{array}$ & 0.984 & 0.973 & 0.002 \\
\hline & CONTAG $^{\mathrm{d}}$ & 93.586-110.405CONTAG & 0.873 & 0.841 & 0.006 \\
\hline$\delta^{15} \mathrm{~N}-\mathrm{NO}_{3}$ & FRAC $^{\mathrm{a}}$ & $-376.783+339.685$ FRAC & 0.998 & 0.996 & 0.030 \\
\hline \multicolumn{6}{|l|}{ June } \\
\hline $\mathrm{NO}_{2}-\mathrm{N}$ & CIRCLE $^{\mathrm{e}}$ & 9.337-12.464CIRCLE & 0.877 & 0.846 & 0.006 \\
\hline $\mathrm{NH}_{3}-\mathrm{N}$ & $\mathrm{SHMN}^{\mathrm{f}}$ & $-53.090+26.290$ SHMN & 0.751 & 0.689 & 0.025 \\
\hline TN & SHMN $^{\mathrm{f}}$ & $-38.129+21.323 \mathrm{SHMN}$ & 0.748 & 0.684 & 0.026 \\
\hline$\delta^{15} \mathrm{~N}-\mathrm{NO}_{3}$ & SHMN $^{f}$ & $-125.484+61.530 \mathrm{SHMN}$ & 0.977 & 0.966 & 0.012 \\
\hline \multicolumn{6}{|l|}{ August } \\
\hline $\mathrm{NO}_{2}-\mathrm{N}$ & FRAC $^{\mathrm{a}}$ & $-3.141+55.479$ FRAC & 0.905 & 0.882 & 0.003 \\
\hline $\mathrm{NH}_{3}-\mathrm{N}$ & $\begin{array}{l}\text { CONTAG }^{\mathrm{d}} \\
\text { SHMN }^{\mathrm{f}}\end{array}$ & $\begin{array}{l}\text { 17.821-27.165CONTAG }+ \\
2.476 \mathrm{SHMN}\end{array}$ & 0.969 & 0.948 & 0.005 \\
\hline TN & FRAC $^{\mathrm{a}}$ & $-8.615+3.329 \mathrm{FRAC}$ & 0.782 & 0.728 & 0.019 \\
\hline$\delta^{15} \mathrm{~N}-\mathrm{NO}_{3}$ & $\mathrm{PRD}^{\mathrm{c}}$ & 14.549-21.693PRD & 0.740 & 0.675 & 0.028 \\
\hline$\delta^{18} \mathrm{O}-\mathrm{NO}_{3}$ & $\begin{array}{l}\text { SHMN }^{\mathrm{f}} \\
\text { PARA }^{\mathrm{b}}\end{array}$ & $\begin{array}{l}-82.475+33.162 \text { SHMN } \\
+0.031 \text { PARA }\end{array}$ & 0.966 & 0.944 & 0.006 \\
\hline \multicolumn{6}{|l|}{ October } \\
\hline $\mathrm{NO}_{2}-\mathrm{N}$ & $\mathrm{PRD}^{\mathrm{c}}$ & 1.258-2.377PRD & 0.709 & 0.636 & 0.035 \\
\hline $\mathrm{NH}_{3}-\mathrm{N}$ & $\begin{array}{l}\text { SHMN }^{\mathrm{f}} \\
\text { CONTAG }^{\mathrm{d}}\end{array}$ & $\begin{array}{l}3.245+1.539 \mathrm{SHMN}- \\
\text { 7.509CONTAG }\end{array}$ & 0.990 & 0.984 & 0.001 \\
\hline$\delta^{15} \mathrm{~N}-\mathrm{NO}_{3}$ & $\mathrm{PRD}^{\mathrm{c}}$ & 17.138-30.313PRD & 0.780 & 0.725 & 0.020 \\
\hline$\delta^{18} \mathrm{O}-\mathrm{NO}_{3}$ & $\begin{array}{l}\text { SHMN }^{\mathrm{f}} \\
\text { PARA }^{\mathrm{b}}\end{array}$ & $\begin{array}{l}-82.285+33.493 \text { SHMN } \\
+0.030 \text { PARA }\end{array}$ & 0.966 & 0.943 & 0.006 \\
\hline
\end{tabular}

a Fractal dimension index.

b Perimeter area ratio.

c Patch richness density.

d Contagion.

e Related circumscribing circle.

f Mean shape index.

\section{Discussion}

\subsection{Effects of land-use types on nitrogen pollution}

In recent years, land-use structure has been changed and landscape fragmentation has been intensified with the urbanization in the Haicheng River basin. Land-use types of the river basin significantly influence the river nitrogen pollution (Bu et al., 2014). In this study, correlation and regression analyses show significant relationships between land-use types and nitrogen variables during different seasons. The results indicate trends also seen in other studies that built-up land, dry farmland, and paddy land uses all have positive contributions to river nitrogen pollution (Woli et al., 2004; Lee et al., 2009), whereas forestland use has negative contribution to river nitrogen pollution (Nakagawa and Iwatsubo, 2000; Piatek et al., 2009). Built-up land use correlates with most of nitrogen variables or predicts them seasonally, indicating nitrogen pollution of the river is directly caused by the discharges of industrial and domestic wastewater in urban areas (Schoonover and Lockaby, 2006; Bu et al., 2011; Wilson, 2015). Nitrogen pollution in June is also partly due to intensive fertilization during the farming season (Ngoye and Machiwa, 2004; Wang et al., 2014), as evidenced here by the correlations between nitrogen variables and agricultural land uses (dry farmland and paddy land). This is in contrast to findings that nitrogen from agricultural soils can be removed by denitrification in cropping systems (Hofstra and Bouwman, 2005). In the more $N$-rich systems of our study area, we could find only marginal evidence for such losses in that agricultural land uses have negative associations with some nitrogen variables in linear regression analysis during August and October.

Forestland plays an important role in water purification and alleviation of water quality degradation due to its negative relation with 
Table 6

Contributions (mean \pm error) of different nitrogen sources to river nitrogen in six zones of the Haicheng River basin, China.

\begin{tabular}{lllll}
\hline Zone & $\begin{array}{l}\text { Synthetic } \\
\text { fertilizer }\end{array}$ & $\begin{array}{l}\text { Domestic } \\
\text { sewage/manure }\end{array}$ & $\begin{array}{l}\text { Soil } \\
\text { organic } \\
\text { matter }\end{array}$ & $\begin{array}{l}\text { Atmospheric } \\
\text { deposition }\end{array}$ \\
\hline Forest-farmland & $19.3 \pm 5.2 \%$ & $45.0 \pm 3.3 \%$ & $35.8 \pm 5.9 \%$ & $/$ \\
Forest & $22.1 \pm 2.5 \%$ & $11.5 \pm 7.0 \%$ & $66.4 \pm 4.5 \%$ & $/$ \\
Farmland-livestock & $23.8 \pm 3.2 \%$ & $43.7 \pm 8.3 \%$ & $32.5 \pm 5.5 \%$ & $/$ \\
$\quad$ rearing & $31.5 \pm 4.2 \%$ & $27.0 \pm 9.9 \%$ & $41.5 \pm 6.8 \%$ & $/$ \\
$\begin{array}{l}\text { Farmland } \\
\text { Residence }\end{array}$ & $/$ & $76.4 \pm 6.0 \%$ & $/$ & $23.6 \pm 6.0 \%$ \\
Farmland-residence & $23.2 \pm 0.8 \%$ & $62.8 \pm 2.1 \%$ & $13.9 \pm 1.4 \%$ & $/$ \\
\hline
\end{tabular}

nitrogen. Some nitrogen pollutants are fixed or adsorbed by forestland effects before running into the river (Nakagawa and Iwatsubo, 2000; Piatek et al., 2009). Nevertheless, forestland combined with built-up land or paddy land in June positively contributes to river nitrogen. This nitrogen is probably associated with the utilization of synthetic fertilizer and animal manure in orchards and managed forest.

Grassland use significantly contributes to the nitrogen pollution of the river in its positive correlations with nitrogen variables, indicating that grassland is not a solution to nutrient pollution control (Ouyang et al., 2010). This is consistent with the study of Ahearn et al. (2005) and may be linked to grassland distributions in the vicinity of agricultural land uses, distributions that do not prevent nitrogen losses through surface runoff (Kaleel et al., 1980).

\subsection{Effects of landscape metrics on nitrogen pollution}

Landscape metrics qualify the land-use patterns and elucidate the spatial heterogeneity and landscape structure (Griffith, 2002). In this study, the shape metrics (SHMN, FRAC, PARA, and CIRCLE), aggregation metric (CONTAG), and diversity metric (PRD) show some correlations with nitrogen variables and predict them over seasons. These results indicate that landscape structure and configuration can affect the river nitrogen through changing the hydrological and ecological processes in the watershed (Turner et al., 2001; Woli et al., 2004; McGarigal et al., 2012; Bu et al., 2014). SHMN, measuring the shape complexity of land uses (Lee et al., 2009) in different zones, shows significant relationships with $\mathrm{NH}_{3}-\mathrm{N}$ during all seasons, implying possible point sources of nitrogen pollution such as domestic sewage and industrial waste waters ( $\mathrm{Bu}$ et al., 2011, 2014). $\mathrm{NO}_{3}-\mathrm{N}$ is only estimated by FRAC in April, suggesting the influence of shape complexity on river $\mathrm{NO}_{3}-\mathrm{N}$ due to human disturbance during this season (Wu, 2007). CONTAG and PRD are negatively correlated with nitrogen variables, reflecting the effects of landscape dispersion and diversity on river nitrogen. A landscape in which patch types are well interspersed will have low CONTAG (McGarigal et al., 2012), which can increase nitrogen pollution by frequent human activities (Uuemaa et al., 2005). Generally, landscape scale effects on river nitrogen pollution would take a long time to become apparent. Hence, river water quality and landscape patterns require a long-term monitoring in the river basin.

\subsection{Effects of land-use patterns on nitrogen pollution sources}

On a landscape scale, the nitrogen sources significantly vary from forested headwaters to densely populated towns of the river basin. In managed forest zone, soil organic matter dominates nitrogen sources. However, synthetic fertilizer and animal manure also contribute to the forest zone since there are orchards and managed forest within the zone. Manure dominates the sources of nitrogen in farmland-livestock rearing zone since livestock produces about 1903 tons/year of $\mathrm{NH}_{3}-\mathrm{N}$ to enter the river (Bu et al., 2011). In forest-farmland, farmland, and farmland-residence zones, synthetic fertilizer is not the main contributor to river nitrogen although approximately $15.0-16.2 \times 10^{3}$ tons of $N$ - fertilizers per year are delivered into the river through surface runoff and/or direct volatilization (Bu et al., 2011). Additionally, residence zone is highly polluted by nitrogen through the production and discharge of sewage since treatment plants could not effectively remove nitrogen from the waste; nitrogen is eventually discharged into the river. The results further indicate nitrogen pollution in the river basin is related to land-use changes (Mattikalli and Richards, 1996), particularly in built-up land use areas discharging wastewater from domestic sewage and/or industries (Bu et al., 2014). In the river basin, about $5.2 \times 10^{6}$ tons/year of domestic sewage including 185 tons of $\mathrm{NH}_{3}-\mathrm{N}$ and $8.9 \times 10^{6}$ tons of industrial wastewater comprising 24.3 tons of $\mathrm{NH}_{3}-\mathrm{N}$ are discharged to the river (Bu et al., 2011).

\section{Conclusions}

This study investigated the effects of land-use patterns on river nitrogen pollution in the Haicheng River basin in Northeast China. Landuse types and landscape metrics were the most important predictors for river nitrogen variables at the watershed scale. Built-up land use was the most consistent and significant predictor for nitrogen variables over seasons, indicating that river nitrogen pollution was mainly caused by industrial and domestic wastewater. Forestland positively contributed to alleviate river nitrogen pollution. Agricultural land use (dry farmland and paddy land) was not a major contributor to river nitrogen pollution. The landscape metrics of SHMN, FRAC, PARA, CONTAG, PRD, and CIRCLE correlated well with most nitrogen variables and predicted them over seasons, showing that landscape patterns contributed to river nitrogen pollution because of human disturbance. Nitrogen sources identified by isotope analysis were dominantly domestic sewage/manure in the watershed, consistent with the important pollution input from built-up land uses.

\section{Acknowledgements}

This research was supported by the Open Funding Project of State Key Laboratory of Environmental Criteria and Risk Assessment, Chinese Research Academy of Environmental Sciences (SKLECRA2014OFP12) and the China Scholarship Council (No. 201404910228). The authors express sincere gratitude to Prof. Brian Fry from Griffith University for his suggestions and the anonymous reviewers for their valuable comments.

\section{References}

Ahearn, D.S., Sheibley, R.W., Dahlgren, R.A Anderson, M. Johnson, J., Tate, K.W., 2005. Land use and land cover influence on water quality in the last free-flowing river draining the western Sierra Nevada, California. J. Hydrol. 313, 234-247.

Bahar, M.M., Ohmori, H., Yamamuro, M., 2008. Relationship between river water quality and land use in a small river basin running through the urbanizing area of Central Japan. Limnology 9, 19-26.

Bu, H., Meng, W., Zhang, Y., 2011. Nitrogen pollution and source identification in the Haicheng River basin in Northeast China. Sci. Total Environ. 409 (18), 3394-3402.

Bu, H., Meng, W., Zhang, Y., Wan, J., 2014. Relationships between land use patterns and water quality in the Taizi River basin, China. Ecol. Indic. 41, 187-197.

Chang, C.C.Y., Kendall, C., Silva, S.R., Battaglin, W.A., Campbell, D.H., 2002. Nitrate stable isotopes: tools for determining nitrate sources among different land uses in the Mississippi River Basin. Can. J. Fish. Aquat. Sci. 59, 1874-1885.

Duda, T., Canty, M.J., 2002. Unsupervised classification of satellite imagery: choosing a good algorithm. Int. J. Remote Sens. 23, 2193-2212.

FAO, 2006. World reference base for soil resources. World Soil Resources Reports. FAO, Rome.

Griffith, J.A., 2002. Geographic techniques and recent applications of remote sensing to landscape-water quality studies. Water Air Soil Pollut. 138, 181-197.

Hofstra, N., Bouwman, A.F., 2005. Denitrification in agricultural soils: summarizing published data and estimating global annual rates. Nutr. Cycl. Agroecosyst. 72, 267-278.

Kaleel, R. Reddy, K.R., Overcash, M.R., 1980. Transport of potential pollutants in runoff water from land areas receiving animal wastes: a review. Water Res. 14, 421-436.

Kang, J.-H., Lee, S.W., Cho, K.H., Ki, S.J., Cha, S.M., Kim, J.H., 2010. Linking land-use type and stream water quality using spatial data of fecal indicator bacteria and heavy metals in the Yeongsan river basin. Water Res. 44, 4143-4157.

Kendall, C., Elliott, E.M., Wankel, S.D., 2007. Tracing anthropogenic inputs of nitrogen to ecosystems, chapter 12. In: Michener, R.H., Lajtha, K. (Eds.), Stable Isotopes in Ecology and Environmental Science, second ed. Blackwell Publishing, pp. 375-449. 
Lee, K.S., Bong, Y.S., Lee, D., Kim, Y., Kim, K., 2008. Tracing the sources of nitrate in the Han River watershed in Korea, using $\delta^{15} \mathrm{~N}-\mathrm{NO}_{3}^{-}$and $\delta^{18} \mathrm{O}-\mathrm{NO}_{3}^{-}$values. Sci. Total Environ. 395, 117-124.

Lee, S.-W., Hwang, S.-J., Lee, S.-B., Hwang, H.-S., Sung, H.-C., 2009. Landscape ecological approach to the relationships of land use patterns in watersheds to water quality characteristics. Landsc. Urban Plan. 92, 80-89.

Liaoning Haicheng Statistics Bureau (LHSB), 2011. Haicheng Statistical Yearbook.

Mattikalli, N.M., Richards, K.S., 1996. Estimation of surface water quality changes in respone to land use change: application of the export coefficient model using remote sensing and geographical information system. J. Environ. Manag. 48, 263-282.

Mayer, B., Boyer, E.W., Goodale, C., Jaworski, N.A., Breemen, N.V., Howarth, R.W., et al., 2002. Sources of nitrate in rivers draining sixteen watersheds in the northeastern U.S.: isotopic constraints. Biogeochemistry 57 (58), 171-197.

McGarigal, K., Cushman, S.A., Ene, E., 2012. FRAGSTATS v4: spatial pattern analysis program for categorical and continuous maps. Computer software program produced by the authors at the University of Massachusetts, Amherst Available at the following web site: http://www.umass.edu/landeco/research/fragstats/fragstats.html.

Mehaffey, M., Nash, M., Wade, T., et al., 2005. Linking land cover and water quality in New York City's water supply watersheds. Environ. Monit. Assess. 107, 29-44.

Nakagawa, Y., Iwatsubo, G., 2000. Water chemistry in a number of mountainous streams of East Asia. J. Hydrol. 240, 118-130.

National Environmental Protection Bureau (NEPB), 2002. Standard Methods for the Examination of Water and Wastewater (Version 4). China Environmental Science Publish Press, Beijing (in Chinese).

Ngoye, E., Machiwa, J.F., 2004. The influence of land use patterns in the Ruvu river watershed on water quality in the river system. Phys. Chem. Earth 29, 1161-1166.

Ouyang, W., Skidmore, A.K., Toxopeus, A.G., Hao, F., 2010. Long-term vegetation landscape pattern with non-point source nutrient pollution in upper stream of Yellow River basin. J. Hydrol. 389, 373-380.

Pardo, L.H., Kendall, C., Pett-Ridge, J., Chang, C.C.Y., 2004. Evaluating the source of streamwater nitrate using $\delta^{15} \mathrm{~N}$ and $\delta^{18} \mathrm{O}$ in nitrate in two watersheds in New Hampshire, USA. Hydrol. Process. 18, 2699-2712.

Phillips, D.L., Gregg, J.W., 2001. Uncertainty in source partitioning using stable isotopes. Oecologia 127, 171-179.
Piatek, K.B., Christopher, S.F., Mitchell, M.J., 2009. Spatial and temporal dynamics of stream chemistry in a forested watershed. Hydrol. Earth Syst. Sci. 13, 423-439.

Rothwell, J.J., Dise, N.B., Taylor, K.G., Allott, T.E.H., Scholefield, P., Davies, H., Neal, C., 2010 A spatial and seasonal assessment of river water chemistry across North West England. Sci. Total Environ. 408, 841-855.

Schoonover, J.E., Lockaby, B.G., 2006. Land cover impacts on stream nutrients and fecal coliform in the lower Piedmont of West Georgia. J. Hydrol. 331, 371-382.

Silva, S.R, Kendall, C. Wilkison, D.H Chang C.C..C. Avanzino, RJ 2000. A new method for collection of nitrate from fresh water and analysis for its nitrogen and oxygen isotope ratios. J. Hydrol. 28, 22-36.

Tran, C.P., Bode, R.W., Smith, A.J., Kleppel, G.S., 2010. Land-use proximity as a basis for assessing stream water quality in New York State (USA). Ecol. Indic. 10, 727-733.

Turner, M.G., Gardner, R.H., O'Neill, R.V., 2001. Landscape Ecology in Theory and Practice. Springer, New York.

Uuemaa, E. Roosaare, J., Mander, Ü., 2005. Scale dependence of landscape metrics and their indicatory value for nutrient and organic matter losses from catchments. Ecol. Indic. 5, 350-369.

Wang, Y., Li, Y., Liu, X., Liu, F., Li, Y., Song, L., Li, H., Ma, Q., Wu, J., 2014. Relating land use patterns to stream nutrient levels in red soil agricultural catchments in subtropical central China. Environ. Sci. Pollut. Res. 21, 10481-10492.

Wilson, C.O., 2015. Land use/land cover water quality nexus: quantifying anthropogenic influences on surface water quality. Environ. Monit. Assess. 187 (7), 424.

Woli, K.P., Nagumo, T., Kuramochi, K., Hatano, R., 2004. Evaluating river water quality through land use analysis and $\mathrm{N}$ budget approaches in livestock farming areas. Sci. Total Environ. 329, 61-74.

Wu, J., 2007. Landscape Ecology: Pattern, Process, Scale and Hierarchy. Higher Education Press, Beijing, pp. 96-119.

Xue, D., Botte, J., De Baets, B., Accoe, F., Nestler, A., Taylor, P., Van Cleemput, O., Berglund, M., Boeckx, P., 2009. Present limitations and future prospects of stable isotope methods for nitrate source identification in surface- and groundwater. Water Res. 43, 1159-1170. 